\title{
Ruská próza s géniom loci
}

\section{Viera Žemberová}

\begin{abstract}
Abstrakt
V príspevku Ruská próza s géniom loci sa pozornosț venuje súčasným ruským prozaičkám, ktoré v odlišných žánroch a s rozličnou tematikou venujú pozornost' spoločensky nerovnakému typu a nerovnakej skúsenosti ženskej literárnej postavy, ktorá je svojimi osobnými dejinami spojená s mestom Moskva. Zmyslom zapojenia ženskej postavy do deja sa stali aktuálne otázky individuálneho vyrovnávania sa s vlastným životom, so zvažovaním, ako ho chránit' pred zmenami, ale aj tým, ako sa sústredit' na zásadnú spoločenskú zmenu hodnoty vlastnej existencie. Spisovatel'ky nemoralizujú, nevytvárajú neriešitel'né sujetové kauzy. Naopak, s nadhladom i vážne premýšlajú, ako uchovat' autenticitu svojej literárnej postavy, prejavit jej osobnost' a vôl'u a ako nerezignovat' na hodnoty, ktoré by naplnili život matky, manželky, uspokojili jej profesijné ambície a uchovali by jej jedinečnost' vo vztahu k tomu, s kým žije a čo preživa. Výber mestskej lokality a jej obyvatel'ov plní funkciu interného etnického znaku a historického symbolu. Univerzálne obnovovanému mýtu mesta Moskva voči iným ruským mestám emotívne porozumejú len jeho obyvatelia.
\end{abstract}

\section{Klúčové slová}

próza; teória textu; motívy; tematika narátorky; postava

\section{Abstract \\ Russian Prose with a Genius Loci}

The contribution Russian Prose with a Genius Loci is focused on current Russian female prose writers who in different genres and different themes pay attention to a socially dissimilar type and dissimilar experience of a female literary character associated through her personal history with the city of Moscow. The purpose of a female character involvement in the plot is based on topical issues of the individual coping with one's own life, consideration how to protect it against changes and concentration on the fundamental social change in the value of one's own existence. The female writers do not moralize, do not create unsolvable subject cases. On the contrary, with a bird's-eye view or seriously they consider how to preserve the authenticity of their literary characters, how to show their personalities and strength and how not to resign from the values that would satisfy the life of a mother, wife, meet her professional ambitions and retain her uniqueness in relation to who she lives with and what she experiences. The selection of an urban location and its population serve as the internal ethnic attribute and historical symbol. A universally restored myth of the city of Moscow compared with other Russian cities is emotionally understood only by its residents.

\section{Key words}

prose; theory of text; themes; female narrator; character 
Mnohoznačnosṫ termínu próza vo svojom, povedzme, univerzálne vyjadrenom obsahu a jeho význame, popri inom, naznačuje nevyhnutné aj náhodné rozličnosti každodenného života, teda jeho všednú a pragmatickú skutočnost'. Vedla prózy vyjadrujúcej obsahy prostej existencie sa do genológie včleňujú v jej druhovej štruktúre aj literárne žánre, žánrové varianty a také formy prózy, kam patrí aj umelecká próza, ktorej sa venuje predovšetkým teória literatúry, teória textu a literárna estetika, za istých okolností aj literárna komparatistika.

Umelecká próza využíva naračné postupy utvorené z témy rozprávaného a zo spôsobu rozprávania, ale to sú už normotvorné súčasti poetológie, stratégie autora aj stratégie textu, teda komponenty kooperujúce s teóriou autorského umeleckého textu zakomponovanou do literárnej estetiky. Medzi nimi sa iniciujú žánrové varianty prózy, ich nezastupitel’né funkcie vo forme epickej prózy, tými sú predovšetkým narátor, postava, sujet, fabula, literárny čas, literárny priestor a tematizovaný problém. ${ }^{1}$

Autor epickej prózy zovrel látku, tematiku do konceptu stratégie autora, ktorá sa dostáva do roly narátora, postavy a do problému, vnáša do noetiky a poetológie prozaického textu projekciu svojho subjektu do celku literárneho diela. Autor sa pre teóriu textu môže ustálit ako literárnovedná kategória, a to vtedy, ked’ sa presadzuje vo výrazovej sústave textu, predovšetkým v role narátora alebo postavy, čím posilňuje vzájomný vztah medzi subjektom autora a literárnym textom. Kontrastom k takto komponovanej stratégii textu sa javí situácia, v ktorej sa subjekt autora umeleckého textu musí odlísiti od autora ako internej, do kompozičnej štruktúry textu zakomponovanej súčasti stratégie textu. ${ }^{2}$

Subjekt autor, ktorý sa v epickej próze stal internou súčastou kompozičných nástrojov, prijíma rolu narátora a funkciu vševediaceho sprievodcu sujetom a fabulou, ktorý si svoju identitu ochraňuje autentickostou a vierohodnostou tých sujetových pohybov a tematizovaných komponentov problému, ktorými sa dominancia jeho prítomnosti v rozprávaní o rozprávanom nespochybní inou literárnou postavou. Nápomocná býva pri tejto stratégii naračná ja-forma rozprávania, ktorá strategicky organizuje literárny priestor, literárny čas, sujet a dynamizuje procesy fabuly nasmerované na riešenie problému a na noetickú a zážitkovú pointu.

Látkové a tematické predpolie prózy, autor zakomponovaný ako subjekt do stratégie textu na organizáciu „príbehovej“ línie a pre spôsob narácie ponúkajú taký typ literárnej postavy, ktorá sa mení na inšpirujúci a súčasne dostredivý impulz na organizovanie sujetu a na spôsob otvárania sekundárnych konfliktov, a to znamená, že sa postava modeluje a stáva sa dominantou kompozičnou zložkou epického celku, teda zasiahne do jeho horizontálnej aj vertikálnej línie, vždy však v súlade s možnostami žánru prózy. ${ }^{3}$

1 ŠÚTOVEC, Milan: O epickom diele. Levice: L.C.A., 1999, s. 77-101.

2 PLUTKO, Pavol: Autor umeleckého diela. Nitra: Pedagogická fakulta, 1992, s. 11-37.

3 PAVERA, Libor - VŠETIČKA, František: Lexikon literárních pojmů. Olomouc: Nakladatelství Olomouc, 2002, s. 286. 
Prózy ${ }^{4}$, ktoré sú erbovo spojené s mestom Moskva autorsky odkazujú na ruské spisovatel'ky literárnej súčasnosti, na Viktoriu Tokarevovú ${ }^{5}$, Ljudmilu Ulickú ${ }^{6}$, Janu Vagnerovú ${ }^{7}$ a Annu Bersenevovú ${ }^{8}$. Mesto Moskva ani v jednej z próz, ktorým sa venuje pozornost', sa nestane literárnym priestorom, v ktorom sa rozvinie „príbeh“, ale ponecháva si rešpektovaný znak historickej a všeobecne známej lokality stelesňujúcej tradíciu, hodnoty, význam a vedomosṫ toho i o tom, čo sa v spoločenskej a kultúrnej pamäti a v dejinách spája s tým, čo sa označuje v plynúcom čase a jeho obsahoch tradične i znakovo za (velko)ruské a za Rusko.

Odlišné autorské dielne spisovateliek súčasnej ruskej literatúry, žánrom i tematicky a stratégiou narácie rozličné literárne príbehy, vo všetkých dominuje postava ženy v azda najtradičnejšej spoločenskej a kultúrnej až kultovej role matky a manželky, ktorú rozprávanie a jeho komponenty nechajú konat tak, aby sa prejavila jej typová, sociálna, profesijná a emocionálna výbava a aby sa z ruskosti protagonistiek nevytratilo ono univerzálne ženské fluidum odvíjané od mýtu femina fatal, ked' si to sujetové okolnosti vyžiadajú, ale nepotlačili sa ani slovanské prejavy ich emancipovanosti nielen v profesii, ale aj v individuálnom vyrovnaní sa s tematizovaným osobným či všeludským problémom zvýrazňujúcim autenticitu, individualitu protagonistky, a to, čo prináša vo vztahu k ženskej postave jej nazerania na čas a hodnotu vlastnej existencie.

\section{Rozumom sa Rusko pochopit' nedá (V. Tokarevová, 2005) ${ }^{9}$}

Literárne všestrannú Viktoriu Tokarevovú, zabývanú v sovietskej literatúre od šestdesiatych rokov minulého storočia, podla autora doslovu k vydaniu súboru próz Řimské prázdniny (2005), Michala Sýkoru, sprevádza vymedzenie, ktorým „V barvitom, byt’ poněkud neprehledném prostředi současné ruské literatury patři Viktoria Samojlovna Tokarevová [...], mezi tradičnějši orientované autory“, a tí neoživujú vo svojich prózach alúzie iniciované ponornostou a híbavostou Dostojevského narácie a nezaujali ich ani postmoderné či surrealistické prúdy. Naopak, svojím videním všedného života, hodnotami uviazanými

4 Termín próza naznačuje poviedku (Tokarevová, Ulická), román (katastrofická, sci-fi, Vagnerová).

5 Viktoria Tokarevová (1937), jej tvorbe sa venuje Michal Sýkora v doslove O Viktorii Tokarevové (In: TOKAREVOVÁ, Viktoria: Římské prázdniny. Brno: Host, 2005, s. 184-188).

6 Ljudmila Ulická (1943): ,je podle ruské i svètové kritiky najvýznamněšri ruskou spisovatelkou posledních dvaceti let" - citované z prebalu vydania ULICKÁ, Ljudmila: Ženské lži. Praha - Litomyšl: Paseka, 2013.

7 Jana Vagnerová (1973): „sa narodila v Moskve v dvojjazyčnej rodine. Jej matka, pôvodom Češka, tam prišla v šestdesiatych rokoch 20. storočia študovat ruský jazyk a literatúru. Jana vyštudovala manažment na Moskovskej štátnej univerzite a pracovala ako tlmočnička a manažérka, č jej umožnilo cestovat po celom svete [...]. Vagnerovej debut Vongozero vznikol zo série zápiskov na webe Živoj žurnal (Živý časopis) v čase, ked’sa v krajine rozšíril vírus H1N1. [...]. Roku 2011 vyšiel v Rusku knižne a vyvolal mimoriadny ohlas", citované z prebalu vydania.

8 Anna Bersenevová, občianskym menom Tatiana Sotniková (1963): „patrí k najpopulárnejším súčasným ruským spisovatel'kám" - prevzaté z prebalu slovenského prekladu Znovuzrodená pre lásku (2013), v ruskom origináli Renata Flori, Moskva, 2010. Pôvodná profesia ju spája so žurnalistikou, čo naznačuje jej štylizačnú zručnoste a literárny záujem o tematizovanie etických, sociálnych, psychologických a vztahových problémov súčasníka.

9 TOKAREVOVÁ, Viktoria: Římské prázdniny. Brno: Host, 2005, s. 12. 
na rodinu, morálku, emóciu a na prácu tematikou a poetikou tradičnejší autori, teda aj Tokarevová, ostali v blízkosti čechovovskej realistickej inšpirácie. ${ }^{10}$ Pri mapovaní poetologického podložia Tokarevovej noetiky a literárnej estetiky sa d’alej upozorňuje v noetike jej próz, ktoré sprevádza prítomnost', uvol’nenost’ a nevtieravý civilizmu, na stratégiu postavy, na funkčné zakomponovanie detailu do naračného celku, na rozvíjanie sujetu kultivovaným verbálnym a situačným humorom, iróniou, groteskou, čo si však žiada pri recepcii hlbšie poznanie sovietskych a ruských historických, spoločenských aj kultúrnych reálií. Tieto osobitosti poetiky a literárnej estetiky prozaičky Tokarevovej sú vždy nenáhlivo otvárané až po bod nekonfliktnosṫ v jej sujetových schémach, za čo spisovatel'ka vd’ačí svojmu nazeraco a kompozične ustálenému záberu do látky a tematiky a do z nich abstrahovaných problémov, ale aj do výberu typu narátorky a d’alších literárnych postáv. Sama o horizonte svojej autorskej stratégie vypovedala Tokarevová takto: „Mým tématem je touha po ideálu. Mưže se zdát, že láska je nezávislá na politickém sytému, jenže se společností souvisi vše a láska neni výjimkou. "11

Zámer pomenovat poviedku Římské prázdniny naznačuje, že sa dovoláva jednak univerzálneho, navyše v čase genézy textu už kultového kontextu jeho zapojenia tematicky prítomného a poznaného v kultúrnom povedomí v modernom (masovom) filmovom umení. Próza Řimské prázdniny v autorskej biografii Viktorie Tokarevovej pôvodne patrí do výberu, ktorý knižne zverejnila v devätdesiatych rokoch. ${ }^{12}$

Triezvost', všedný deň s jeho rituálom a naoko nevýnimočnost̉ situácie naznačuje expozícia poviedky a situácia narátorky v role postavy rozpomínajúcej sa na to, čo sa už udialo a patrí do análov jej súkromia: „Jednou v mém domě začal dlouze vyzvánět telefon. Meziměsto, pomyslela jsem si a zvedla sluchátko. Volali opravdu z jiného města. Z Řima. Mužský hlas pozdravil francouzsky [...]. Valerio Bettoni, představil se hlas. Advocato Fedrico Fellini““.13 Očakávané očarenie tým, ale aj z toho, že sa do jedného bodu ako náhoda či osud dostane taliansky režisér Fellini a jeho advokát, ktorý vybavuje pracovné stretnutie medzi ním a vo svete neznámou ruskou publicistkou a scenáristkou, k tomu večné mesto Rím a jeho filmové ateliéry, vidina cesty z Moskvy do zahraničia, pritom sa nič z toho nepresunie do epicentra stratégie textu. Žiadna eufória, nijaký výkrik štastia o konečne sa plniacom sne, nijaká vidina dotyku so Západom a iným životom, aký postava denne napĺña vo svojej práci, v rodine a so známymi. Naopak, narátorka postupne ponúka osobné, humorné i krutejšie perličky a detaily, ktorými problematizuje seba a svoj ruský svet, a to vtedy, ked' advokát: „Byl přesvědčen, že ovládám všechny evropské jazyky“, aby dotiahla svetoobčianske gesto „nadradenosti“ dorozumenia sa so všetkými po zovšeobecňujúcu neosobnú skúsenost: „Malé odbočeni. Jednou jsem vystupovala na Západě se známým ruským básnikem. Z hlediště mu zadali otázku: Vy jako predstavitel tvưrči inteligence. Jak je možné, že neznáte jazyky? Aspoň angličtinu [...] Odpovědel skvěle. Řekl: Básnik toho může tolik neznat...! "Prozaik toho také může

10 SÝKORA, Michal: O Viktorii Tokarevové. Doslov. In: TOKAREVOVÁ, Viktoria: Ř́mské prázdniny. Brno: Host, 2005, s. 184.

11 Ibidem, s. 186.

12 TOKAREVA, Viktoria: Sentimentalnoje putěšestvije: pověsti, rasskazy. Moskva: EKSMO, 1997 (Prevzaté z edičnej poznámky výberu Tokarevová, Viktoria: Ǩimské prázdniny. Brno: Host, 2005, s. 189).

TOKAREVOVÁ, Viktoria: Římské prázdniny. Brno: Host, 2005, s. 7. 
tolik neznat. Znalost - to je informace. Ale v tvorbě je důležitá intuice. Člověk může mnohé znát, ale prritom nemít talent. Ale existuje ještě třetí možnost: hodně znát a mít talent. Jako např́klad Puškin. Dně̌ni maska sovětské inteligence je šedivá jako ranni svitáni. Vyhraněni specialisté. $S$ vědomostmi, ale malými“ (s. 7-8).

Čas medzi prijatým medzimestským telefonátom so správou, že sa s narátorkou potrebuje stretnút Federico Fellini a tým, kým sa sovietska administratíva rozhodne jej zaopatrit dokumenty na vycestovanie až po znova mierne komplikované docestovanie do Talianska a obštrukčné stretnutie s Fellinim, rieši Tokarevová kompozične a voči fabule logickou postupnostou, teda literárnym časom. Kompozičné zapojenie kategórie času do rekonštrukcie toho, čo bolo, ked’ bola v Taliansku, presúva spontaneitu výpovede do reflexie zážitku, spomienky a vyhodnocovania zmyslu „príbehu“. Aj preto literárnemu času pripisuje funkciu komponentu s tenziou osobne prenášanou do nudnej a ničím invenčným nepoznamenanej profesijnej skúsenosti, neobíde ani funkciu naračného strihu vnášaného do literárneho priestoru, sujetu a do pripravovanej pointy. Čas narácie má určujúce poslanie skratky medzi príčinou a následkom pôvodného „príbehového“ zámeru, tvorí podložie na odd’alovanú cestu na stretnutie s režisérom Fellinim až po post factum zhodnotenie výsledku: „Snila jsem o práci s ministrem, který by byl na prvním mistě od začátku. Před nim nikdo. Jen Pán Bưh. A jestli mi to z nějakého důvodu nebude souzeno, napiši tuto povidku“ (s. 40).

Narátorka zvolila kompozičnú schému z rekonštrukcie profesijnej spomienky a individuálnej skúsenosti. Jedno i druhé aktualizuje triezvo, realisticky a v sekvenciách, teda ide o pripomenutú kategóriu literárneho času, ktorý vo svojich intervaloch v rozprávaní o tom, čo sa stalo, ked' bola v Ríme, ostáva rapsodický, a to znamená, že narátorke nezáleží na verifikácii, ale na sebaidentifikácii s tým, čo bolo a ako to bolo a s kým to bolo, ked' mala spolupracovat's Fellinim, čo rekonštruuje formálne v poviedke sekvenciami $O$ měsíc později (Bydlím na chalupě a stavím plot.), Druhý den ráno (Odjíždíme, já a Claudia, do Bettoniho sídla v centru Říma.), U moře (Hotel Duna leží na samém břehu Středozemního moře.), Pláž (Na pláži máme k dispozici modrý slunečník a dvě lehátka.), Týden poté (Už si nevšímam bílých stěn).

Popri kategóriách literárny čas a literárny priestor (narátorka si počína tak, že vyvoláva potrebu verifikácie ňou zverejnených reálií a údajov $\left.{ }^{14}\right)$, pracuje s kompozičnými blokmi a nimi exponuje vo svojom rozpomínaní sa na minulé to („Malé odbočeni" $)^{15}$, čo presúva pozornost’ z narátorky na d’alšiu literárnu postavu („Federico zatím začal vysvětlovat smysl našeho setkání. Mluvil o tom, co už jsem věděla: o projektu filmu o Rusku, o tom, že neni novinář, ale publicista, nezná Rusko, nesnáši cestovávni a tak dál a tak dál. Chce si se mnou promluvit a něco si vnitřně ujasnit" $)^{16}$, ktorú svojím detailným pozorovaním odmýtizuje, humanizuje, a tak mierne bagatelizuje jej výnimočnost’ a neskrýva svoje rozčarovanie („Děkuji vám za pozváni, řekla jsem Federicovi. Ale jsou daleko zajímavějši Rusové. Možná

14 Autentickost prozaickej rozpomienke na cestu zo ZSSR do Talianska podporila uvádzaním konkrétnych dátumov a konkrétneho času, desatročí, verifikovatel'nými priezviskami postáv popri iných, ktoré sú kalkami, názvov reálnych mestských a kultúrnych lokalít, odkazmi na literárne a filmové projekty atd’.

15 TOKAREVOVÁ, Viktoria: Řimské prázdniny. Brno: Host, 2005, s. 11.

16 Ibidem, s. 24. 
byste si měl promluvit s nimi. To by nikdy neskončilo!, energicky namitl Federico. A ja jsem si uvědomila: on nechce zajímavějši Rusy a nechce dělat film o Rusku [...]. K čemu je mu Rusko, cizi a nepotrebná pevnina?"). ${ }^{17}$

Próza, ktorá absorbuje autobiografické a verifikovatel’né podložie zakomponované do literárneho priestoru, do postavy alebo do kontextových spoločenských, kultúrnych a politických reálií nechýba v Tokarevovej poviedke ani v odkazoch („Je špatné a naivní si myslet, že u nás v socializmu nic není. Máme v̌̌echno: milionáre, narkomany, homosexuály“ (s. 18-19); „O čem chcete mluvit? Co vás o Rusku zajimá? Obvykle se všichni ptaji na pěrestrojku a kdo se mi líbi víc: jestli Jelcin, nebo Gorbačov. Jelcina zbožňuji, mimochodem jako všichni. Ale pro mě konkrétně Jelcin neudělal nic. Gorbačov mě posadil k jednomu stolu s Federicem Felinim “ (s. 27); „Po stalinských mrazech se zaradovali, z chruščovovské oblevy zpitomněli, a tak zamrzli na dvacet let“ (s. 41); „V kapitalizmu je všechno, jenom ne to, co člověk potřebuje“ (s. 37)).

Tokarevová na podloží poviedky navrstvila viacero mikroplôch utváraných princípom široko roztvoreného kontrastu spomedzi reálií a fikcie, ale v podstate sa sústredila na osobitost’ svojej narátorky, na to, čo ako vzdelaná, skúsená, mechanizmom moci obrúsená realistka absorbovala $\mathrm{v}$ inom svete a s inou profesiou, s rozličným štýlom postoja k realite, než v akom žije a chce žit, aby skúsenost’ sústredila do dvoch opät tenzijných postojov utvorených z vysokej kultúrnej tradície („V Moskvě bylo větrno. Jako u Čechova: A počasí je, jako by mělo každou chvili začít chumelit" (s. 41)) a nízke, možno zo strohej spoločenskej, medziludskej komunikácie („Kam to házíš?, pokřikuje pohoršeně. Celá Moskva už je zasraná“ (s. 42)) a nezvratne sa blížiacej budúcnosti („Nějaký pán Tumba koupil kousek pridy, oplotil ho, zasel tam trávu a založil golfový klub. Za valuty. Hrávaji tam přvvǎně Japonci. [...]. Zelené pole se táhne po svahu skoro až ke kapličce. Krásná starobylá kaplička postavená pred dvěma třema sty lety. Zajimavé. Jestli pak koupil i kaplicku?" (s. 42)).

\section{Ajhla, ako je človek zložitý, kolko rozličných vecí sa v ňom skrýva... (L. Ulická, 2013) ${ }^{18}$}

Próza Viktorie Tokarevovej spočinula vo výpovedi narátorky, ktorá si osvojila čas ako spomienku, priestor ako súčast’ pocitovej pamäti a vierohodnost’ prelínania fikcie a faktu podporila aktualizovaným spoločenským kontextom s ambíciou predstavit’ ruskost̉ ako mravnú a rozumovú hodnotu svojich súčasníkov.

Ljudmila Ulická v próze pracuje s detailom, jednotlivcom, dôveruje zovšeobecnenej povesti všetkého, čo je ruské ako ustáleného národného koloritu, do ktorého sa v jej práci s postavou a narátorkou sústredilo historizujúce povedomie o krajine a jej obyvateloch. Ženská postava si v psychologizujúcej próze vyžaduje precízne zachytenie typu, sociálneho pôdorysu a osobnostnej výzbroje, aby obstála v kolektíve d’alších všedných ruských žien, ktorými sú jej rovesníčky a súčasníčky. Z poviedkového výberu Ženské lži

17 Ibidem.

18 ULICKÁ, Ljudmila: Ženské lži. Praha - Litomyšl: Paseka, 2013, s. 62. 
(2013) sa zámer sústredit do toho istého priestoru a s tým istým problémom viacero ženských typov naplnil v poviedke Diana (s. 7-36).

Ruské skoré a chladné májové leto, vyhl’adávané ruské letovisko s ned’alekým morom a plážou, ubytovanie v súkromí, kde je viacero izieb na prenájom, matka Žeňa s chorlavým synčekom Sašom, vznikne nečakane takmer javisková scéna, v ktorej „Tak ti dva spolu žili celý týden ve velkém domě, v nejmenšim pokoji, všechny ostatni, pečlivě uklizené a uchystané k nastěhováni čekaly na hosty. [...] Žili si tak krásně a spokojeně, že Žeřa dokonce zapochybovala o lékařských diagnózach, ktoré dětští psychiatři stanovili jedimu divokému a impulzivnímu dítěti. Žádné scény, žádné hysterické výstupy snad by se dal považovat $i$ za poslušné dítě, kdyby Žeňa měla jasnou představu o tom, co to vůbec „poslušnost“ znamená..." (s. 9-10).

Moskovčanka Žeňa rada číta, oddychuje s príbehmi literárnych hrdinov a miluje svojho neposedného syna. Hlučná a excentrická obyvatel'ka Moskvy Diana, s oblubou popíja a kriminálne fabuluje minulost̉ svojich rodičov, ktorou fascinuje Žeňu. Diana dennodenne rozširuje svoje osobné dejiny o nové a vypätejšie epizódy, ktorými postupne oživuje a formuje tretiu, virtuálnu ženu - seba s menom Diana. Dianino pitie patrí k jej spoločenskému koloritu, ktorý okolie toleruje: „Dvě lahve portského. S vinem to bylo v tom roce skvělé: Gorbačov na ně ještě nezaútočil a krymská vína vyráběly sovchozy, kolchozy $i$ dědci soukromníci $[\ldots]$ “..) (s. 14). Žeňa zotrváva v zajatí tragickej nevšednosti svetáčky Diany a jej osobného príbehu do chvíle, kým nepríde čas na pravdu s pevným bodom presahujúcim dovtedajšie citové a mravné ataky na predstavivost̉ dôverčivej osamelej ruskej ženy z velkomesta, pretože vel'komestské Dianino rozprávanie o invalidnej matke, perzekvovanom otcovi, o nespočítatel'ných milencoch, dvoch manželoch a detoch, o holandskom zahraničí a sovietskej politickej perzekúcii jej rodiny v moskovských časoch, sa rozbije na črepiny z faktov, aby konfrontované s pravdou sa Dianino fabulovanie zastavilo v bode, ked': „Obě historie se protínaly v tom nejnepravděpodobnějším mistě - v rezidentské minulosti irsko-britského komunisty, odsouzeného k trestu smrti a vyměněného za sovětského špiona..." (s. 33).

Žeňa pred tým, „co ani nikdy neexistovalo“ (s. 34) zo spoločného letoviska pred pravdou o Diane, pred jej ponižujúcimi klamstvami, emotívne atakujúcimi príhodami z jej intímnej minulosti, jednoducho utečie. Dianine historky presakujúce z intímneho dejepisu do nie tak dávnej histórie krajiny zapustili v Ženinom precitlivenom materskom vedomí tak hlboké korene, že rozumom prijatá pravda o výmysloch a vedomých klamstvách sa v Ženinom vedomí oddelí od reality a znova, z vlastnej vôle, precituje z nedávnych manipulatívnych rozprávaní to, že život je aj iný, ako ho pozná a prežíva sama so synom. Manipulácia iným človekom, privlastnenie si emócií a porozumenia inej osoby, ambícia preniest' do jej vedomia zárodky nateraz neprebudenej schopnosti ovládat život iných, v tom spočíva jedinečnost' Ulickej ženskej postavy. Autorka vie, že sa jej prostredníctvom dotkla nástroja, ktorý má nadčasový a univerzálny účinok, ved' nesie v sebe záznam moderného dejinného podobenstva, ked’ sa aktivizuje kýmsi a kdesi, no predovšetkým v pravý spoločenský, politicky, dejinný čas na skupine/mase utvorenej z jednotlivcov, ktorí žijú v zajatí osobnej malosti, opustenosti, preto tak účinne nalomí a nivočí príčinu a podstatu poznania vlastného neštastia, bezvýznamnosti. V tom spočíva túžba a vyčkávanie na zmenu, ktorú má či musí spôsobit niečo či niekto iný. A tak (iba) vytrvalo čakajú na príležitost’ obrátit vo svoj prospech svoj nežičlivý osud. 
Ulická tematizuje techniku zrodu osudového klamstva, ale napovedá vážnejšiu skutočnost', a tá nastane vtedy, ked’ už akosi niet sily na to, aby sa žilo zo zvyku, lebo už sa nechce živorit’ so svojimi autentickými osobnými a spoločenskými dejmi a dejinami. Čas alter ega azda naznačuje príležitost̉ na útek, cestu, putovanie kamsi inam, ale niet kam uniknút, ani nie tak pred sebou, ako pred kolektívnou pamätou. Ulická nemá prečo zmýšlat inak, ako jej rozprávačka, a to preto, lebo svoj tieň človek neprekročí, nech robí, čo robí.

\section{Nechod'me cez Piter, tam je určite taká istá anarchia ako v Moskve (J. Vagnerová, 2013) ${ }^{19}$}

Román Jany Vagnerovej Vongozero (2013) unesie viacero odkazov na možné žánrové spresnenie: cestopis, katastrofický, fantazijný, rodinný román, ale aj román putovanie, román o nádeji, tematicky sa viaže na literárnu výpravu za záchranou života ruskej rodiny z okraja Moskvy pred neliečitel’nou epidémiou, ktorá vypukla v Moskve a bez účinných zásahov vedenia krajiny a zdravotníckej služby ohrozuje všetkých a všade. Všetko, čo je podstatné pre naráciu, výber postavy, pre sujet a komponovanie fabuly, začalo ako ústne rozšírená zvest’ o vraždiacej epidémii v Moskve, ved’ „Moskva je mŕtva“ (s. 235). Najskôr pohltila obyvatel'ov vel'komesta, emocionálne znefunkčnila rozprávačku po zistení, že jej matka v Moskve už nie je medzi živými, aby sa mesto Moskva oddelilo od ostatných častí krajiny tým, že sa so svojou tragédiou premení na uzavreté a na zánik odsúdené mesto, ktoré nedokázalo zastavit’ epidémiu a Moskva dovolila, aby sa „smrt“ šírila chaoticky aj kruto po celej krajine. Bez toho, aby sa naznačilo, kto sa o zastavenie ničivého ochorenia v meste, v krajine skutočne stará, ako sa správa vedenie mesta, čo sa rozhodla nie raz aj tvrdšie skúšaná krajina vykonat na svoju záchranu. Vel'komesto Moskva, odkial' sa riadi celá krajina a ruská „zem“, dostanú sa do podložia katastrofickej témy, čím nastáva naračná príležitost̉ na sledovanie dramatickej cesty ako úniku pred smrtou a nevypočítatelnostou l’udskej zákernosti k vysnívanému jazeru na severe ako k miestu záchrany života. Cesta k jazeru premenená na únik pred smrtou a l’udskou existenciálne naznačenou zákernostou sa rozvinie do kaleidoskopu karikatúry l’udských mravných prototypov, ktoré na ceste za životom utekajúca rodina stretne, pozná a okúsi prax „človečiny“, lebo prestali platit’ zákony, nariadenia a vrchnost’ krajiny nie je pri moci. Všetko, o čo sa postavy usilujú, skúšajú, nachádzajú ako príležitostné riešenie, spočinie na intuícii, na živočíšnej odvahe, na vztahovej mobilite postáv, ktoré autorka nechá spontánne konat. Zvnútorneným mottom sujetu sa stala globalizujúca sentencia s racionálnym jadrom: „V časoch ako tieto, neplatia zvyčajné morálne pravidlá" (s. 181).

Epicentrom prehlbujúcej sa tragédie úsilia o záchranu a prežitie najbližších sa stala trojčlenná mladá, vzdelaná, harmonická rodina, ktorá prirodzene podlahne kríze osobnej katastrofy a vyrovná sa s obavou veštiacou to najhoršie, „nedôjdeme“ (s. 281). Najskôr z jej členov stratí dcéra matku v Moskve, potom si uvedomí ona a jej rodina, hoci nežijú priamo v Moskve, že i napriek zanedbatelnej vzdialenosti od vel'komesta, predsa sú v tesnej blízkosti šíriacej sa epidémie a bolestivej smrti: „Začína sa to ako obyčajné prechladnutie 
- máte triašku, búši vám v sluchách, bolia vás klby, ale cítite sa ešte celkom dobre, môžete chodit, rozprávat' sa, šoférovat', no pritom už infikujete l’udi, v blizkosti ktorých sa nachádzate, nie všetkých, no mnohých. Ked' prepukne horúčka, už nemôžete chodit’..." (s. 88).

Poznanie, že na záchranu života a rodiny ostáva len únik a nutnost’ ocitnút sa čo najd'alej od Moskvy, hoci racionálne úvaha napovedá, že pred agresívnym ochorením niet záchrany, to sa stáva sujetom románu, bolo by možné pripojit k žánru Vagnerovej románu aj d’alší prídavok: „Vongozero je pozoruhodný postapokalyptický triler. Vyvoláva strach a núti premýšl'at', číta sa jedným dychom a ako nočná mora nikoho nepustí zo zovretia. Je to román napisaný v najlepšich tradíciách Stephena Kinga. " ${ }^{20}$ Každý z aktualizovaných žánrových prívlastkov napovedá jedno, spisovatel'ka napätiu navodenému márnym únikom pred epidémiou, ale skoro sa ukáže, že sa uniká pred l’ud’mi, ktorí proti epidémii vykročili cestou sebeckosti, krutosti, drancovania a zabíjania, sa nesústredila na prepracovanie literárnej postavy. Typológiu či psychológiu postavy nahradila gradáciou kontrastu odvíjaného od morálnych hodnôt civilizovanej spoločnosti a žánrovým pomedzím, aké jej poskytli schémy cestopis a dobrodružný žáner, hoci sama naznačuje, že pracovala na katastrofickej projekcii tézy, čo by sa stalo, keby sa stalo práve toto. Predpoklad, že ženský prvok bude v próze dominovat', oslabujú schémy pripomenutých žánrov. Akčnost̉ príbehu a stupňovanie naračného záujmu o jednotlivca aj typovo odlišne zostavené skupiny postáv v existenciálnej situácii sa presunuli na rázne činy a rozhodnutia najstaršieho muža, veterána, skúseného polovníka a svokra/otca, ktorý dokáže po peripetiách s trasou cesty na sever k jazeru, po rozplynutí sa naivnej predstavy o l'udskosti a pomoci v situáciách hraničiacich s útrapami, ako prežit’ a blízkostou smrti, dovedie svojich najbližších k jazeru.

Narátorka, ktorá v priamom prenose zaznamenáva a komentuje všetko, čo postavy podstupujú na svojej ceste autami k jazeru s vidinou záchrany svojich životov, zapojí do atmosféry ponurosti a úzkosti takmer nadliahčujúci postreh: „Je zábavné, čo všetko nové sa človek dozvie o svojich bližnych, ked'sa s nimi ocitne v podobnej situácii [...]“ (s. 195).

Lineárne komponovaný príbeh je osnovaný na situačnom a epizodickom napätí, ktoré na seba viaže kompozícia, hoci postavy spája jediná, existenciálne vystupňovaná myšlienka: „len nech už sa skonči táto prekliata cesta“ (s. 308). Paradoxne, ale s prihliadnutím na žáner, takmer ako želané podobenstvo, účinkuje ilúzia, že ide iba o počítačovú hru, hoci je realistická a strašná, pritom sa stačí vrátit o krok spät, zrušit chybné rozhodnutie a nič z toho, čo prežívajú, nebude súčastou ich literárneho života (s. 151).

Vagnerová nerozvíja svoje literárne postavy, ponecháva ich v expozičných typových vzorcoch, ale sa sústred’uje na ich správanie navodené ohrozením, strachom, úzkostou, skratovými činmi a rozhodnutiami skupiny l’udí na úteku pred epidémiou aj v súkolesí rozhodnutí retaziacich existenciálne situácie z putovania čo najd’alej od Moskvy. Niet inej ponuky a možnosti, ako sa zachránit pred smrtou, po „Rusku sužovanom epidémiou. Poslednou nádejou je zamrznuté Vongozero" ${ }^{21}$.

V románe sa navrstvuje narácia, próza taží z opisov, ktoré musia udržat pozornost́ čitatel’a, napätie a dobrodružnost' spôsobia, že Vongozero ako celok ustupuje pred estetickou hodnotou a artistnostou rozprávania.

20 Prevzaté z prebalu slovenského vydania románu Vongozero, 2013.

21 Prevzaté z titulnej strany románu Jany Vagnerovej. 


\section{Jednoducho sa nepodobáte na Petrohradčanov, ktorí sú náchylní prest'ahovat' sa do Moskvy (A. Bersenevová, 2013)22}

Génius loci ruského vel'komesta Moskva v prózach autoriek aktivuje do tematiky a do výberu literárnych postáv len to, čo v národnom a nadnárodnom kultúrnom kontexte mesto abstrahuje ako dejinný a hodnotový symbol zachytený v časovej následnosti udalostí viazaných na urbánny priestor a súčasne nezamenitel’ný identifikačný prvok prejavu etnicity a osobitosti spoločenského významu, ktorý sa aktualizuje v literárnom príbehu ako priestor prenosný na zhodnocovanie súvislostí odohrávajúcich sa alebo zviazaných s geograficky rozsiahlejším priestorom krajiny na vymedzenie zal'udneného organizmu samotného mesta a jeho rytmu života, mravnosti, zvykov, početnosti, mnohorakosti a odlišnosti „tu a teraz“.

V próze A. Bersenevovej Znovuzrodená pre lásku (2013), ktorá sa nevzoprie vymedzeniu populárna literatúra ${ }^{23}$, sa v príbehovej línii textu aktualizujú azda všetky zložky tradične vyrozprávaných romantizujúcich príbehov o žene v priesečníku viacerých vztahov s mužmi, o mladej aj zrelej žene v role osamelej matky, ktorá nezapochybuje o tradičných spoločenských emblémoch zo sveta žien, kam patrí láska k mužovi, založenie rodiny, túžba po dietati a profesia predurčujúca ju na pomoc l’ud’om ako oddávna voči profesii lekára udržiavaná povinnost’ a jedna zo zložiek ich prítomnosti v živote, ale zvlášt ako mravný výraz hodnôt ich existencie. Táto lineárna príbehová línia najskôr dokázala zabezpečit výšku nákladu, ktorý sa zvýraznil na titulnej strane textu, lenže text zaujme čímsi iným: predovšetkým do kontrastu postavenou rolou, ktorá sa pripíše vel'komestu Petrohrad a Moskva, vlastnostiam a osobným danostiam formovaným životom v nich, zdá sa aj neprenosným historickým určením postavenia mesta $v$ dejinách krajiny. Petrohrad a Moskva sú tie kontrastné priestory, podla pohybu protagonistky zaujímajú kompozičnú pozíciu konštantného priestoru, no po jej uprednostnení osobného nad profesijným sa priestor lokality z konštantnej mení na priestor otvorený aj migračný ${ }^{24}$. Autorka vytvorila latentné tenzijné miesto, ktoré nastupuje do záverečnej časti príbehu, pritom signalizuje iba zmenu v sujete, a to vtedy, ked’ sa mení stratégia narátorky a nadväzuje nové spojenie so strohejším typom mužskej postavy. V tomto sujete (Renáta - Alexej) zohráva verbálny

22 BERSENEVOVÁ, Anna: Znovozrodená pre lásku. Bratislava: Ikar, 2013, s. 175.

23 Populárne čítanie, ako ho vymedzuje Peter Liba, sa viaže na recepčnú zložku umeleckého textu. V literárnohistorickom procese sa z rozhrania vysoké a nízke a z podložia literárnej estetiky do tejto hodnotovej línie presúvajú aj tie texty, ktoré v čase svojho prvého vydania plnili závažné ontologické poslanie. Na titulnej strane slovenského vydania Znovuzrodená pre lásku umiestnil vydavatel’ reklamnú informáciu „tri milióny predaných výtlačkov“, tá poskytuje viacero možných postojov voči Bersenevovej textu, no nemôže limitovat artistnú ambíciu autorky, ktorá vo všednom príbeh zo života svojej súčasníčky vypovedá o aktuálnom chápaní žien svojej roly v jej osobnom čase, profesii, vztahoch, ponúka predstavu o rodine, čím sa autorka zapája do sociologického vyjadrenia aktuálneho prístupu k diferencovanému chápaniu súčasnej ženy ako modernej, vzdelanej, sebavedomej, schopnej bytosti, ktorá riadi svoj osud a svojimi aj nekonvenčnými rozhodnutia dotvára aktuálny interpretačný prístup k súčasníčke a jej osobnej hodnote zvolenej pre osobný a spoločenský život, uplatnenie sa v dynamickej spoločenskej praxi.

24 PAVERA, Libor - VŠETIČKA, František: Lexikon literárni pojmů. Olomouc: Nakladatelství Olomouc, 2002, s. 290-291. 
medziludský kontakt práve ono, banálne čierno-bielo navodzované génius loci medzi Petrohradčankou a Moskovčanom.

Ani jeden z predchádzajúcich textov nevytvoril tak ostrú hranu medzi mestskými lokalitami a ich tradovaným aj udržiavaným tenzijným pomerom, ktorému do hĺbky i detailu porozumejú len ich (neliterárni) obyvatelia. Génius loci vel'komiest sa objasní na pozadí dejín, tradície a odlišností, ktoré patria a súbežne latentne vzd’alujú jedno vel'komesto od druhého. Bersenevová príbeh zrelej lekárky Renáty Flori, ktorá neuveritel’ne lahko a bezbolestne rezignuje na svoju profesiu, hoci sa práve o nej traduje, že ostáva najvyšším poslaním v živote toho, kto také vzdelanie získal. Narátorka postupne a nenáhlivo sa posúva po rebríčku romantizujúcich (Petrohrad: zrušenie zásnub, pomer s primárom, dospelá dcéra s rodinou v zahraničí; Moskva: dalšie tehotenstvo vo vyššom veku, finalizovanie citového vztahu s drsnejším typom muža) a romantických obetovaní sa pre iného (terapeutka labilnej Tiny), aby sa jej ústupky i zanovitost', ale predovšetkým cesty medzi dvoma vel'komestami premenili na pozitívnu osobnú satisfakciu: svoj život naplní láskou, potomkami, vnúčatami a pevným, spolahlivým, citovo oddaným mužským partnerom. Presuny medzi vzdorom a naivnostou, odchodmi a príchodmi, nádejou a prehrami uzatvára pointa s príslubom štastného konca, teda tak, ako si to žiada konvencia populárneho čítania. Kontrast miest nemá pre komponovanie fabuly iniciačný význam. Petrohrad a Moskva do fabuly vstupuje $\mathrm{v}$ takmer finálnej časti príbehu o hladaní štastia v živote modernej a vzdelanej ženy. To, čo v tomto príbehovom podloží sa v Bersenevovej Znovozrodení pre lásku signalizuje už v názve slovenského prekladu a ráznejšie vyznieva v pôvodine Renáta Flori, ponúka do etiky a morálky ruskej súčasnosti podnety na spoločensky rešpektovaný status viacerých vztahov v živote jednej ženy a uplatnenie jej vôle, ked'sa rozhodne stat sa matkou dvoch detí bez pevného rodinného zázemia a bez otcov svojich detí.

Tradičná maskulínna rola muža v živote ženy a rodiny je v Bersenevovej próze otrasená a pripravená azda o všetky dobré pridané spoločenské aj osobné hodnoty. K tradičnému prejavu ich morálnej a citovej nespol’ahlivosti autorka vytvorila ženskú postavu, ktorá dokáže vlastným rozhodnutím riadit svoj život. Všetko, čo by vytváralo filozofujúcu líniu takto zvoleného postoja k vlastnej existencii a miestu v spoločnosti autorka ponechala mimo mikropodnetov na rozvíjanie príbehovej a sujetovej línie, a to preto, lebo sa spol’ahla na mýtus genia loci a na ich povest’ v ruskom prostredí, ktorá naznačuje, že tí z cárskeho mesta sú iní, poddajnejší ako tí, čo svoju existenciu spojili s rozlahlostou, otvorenostou inému svetu, a predsa ostáva hlavným mestom ruského štátu.

Ak platí, že sa estetická hodnota utvára aj prostredníctvom estetického zážitku²5 a má schopnost' upozornit na predpokladaný hodnotový prvok organizovaný na podloží estetického postoja vyjadreného stratégiou autora a rozvinutou v stratégii textu ${ }^{26}$, potom každá z autoriek a pripomenuté prozaické texty s dominantnou narátorkou ponúkli špe-

25 „Môžeme sa spol'ahnút', že dielo, ktoré sa páčilo povrchnému publiku [...] čas znehodnotí, a naopak, že docení a posväti dielo, ktoré prvé publikum pre jeho náročnost' odmietlo" (COMPAGNON, Antoine: Démon teórie. Literatúra a bežné myslenie. Prel. J. Truhlářová. Bratislava: Kalligram, 2006, s. 274).

26 PECHAR, Zdeněk: Otázka estetické hodnoty v literárním díle. In: POSPÍŠIL, Ivo (ed.): Aplikace a reflexe filozofických, psychologických a sociologických koncepcí v literatuře 19. a 20. století. Brno: Tribun EU, 2014, s. 120 . 
cifický prístup k možnosti zatažit prozaický text morálnym, psychologickým a noetickým uvažovaním o súčasnosti ako o existenciálnej skúsenosti a prostredníctvom pointy svojich príbehov reagovat na kultúrnu a spoločenskú autopsiu a na jedinečné chápanie funkcie epickej prózy v poznávaní dotykového miesta medzi výzvou umenia a jej uskutočnením v neliterárnych súvislostiach.

\section{Umelecká literatúra}

BERSENEVOVÁ, Anna: Znovozrodená pre lásku. Bratislava: Ikar, 2013.

TOKAREVA, Viktoria: Sentimentalnoje putěšestvije: pověsti, rasskazy. Moskva: EKSMO, 1997 (Prevzaté z edičnej poznámky výberu Tokarevová, 2005, s. 189).

TOKAREVOVÁ, Viktoria: Římské prázdniny. Brno: Host, 2005.

VAGNEROVÁ, Jana: Vongozero. Bratislava: Ikar, 2013.

ULICKÁ, Ljudmila: Ženské lži. Praha - Litomyšl: Paseka, 2013.

\section{Literatúra}

BLANCHOT, Maurice: Literárni prostor. Přel. M. Kohoutová - M. Pacvoň. Praha: Herrmann \& synové, 1999.

COMPAGNON, Antoine: Démon teórie. Literatúra a bežné myslenie. Prel. J. Truhlářová. Bratislava: Kalligram, 2006.

PAVERA, Libor - VŠETIČKA, František: Lexikon literárních pojmů. Olomouc: Nakladatelství Olomouc, 2002.

PLUTKO, Pavol: Autor umeleckého diela. Nitra: Pedagogická fakulta, 1992.

PECHAR, Zdeněk: Otázka estetické hodnoty v literárním díle. In: POSPÍŠIL, Ivo (ed.): Aplikace a reflexe filozofických, psychologických a sociologických koncepci v literature 19. a 20. století. Brno: Tribun EU, 2014, s. 120.

SÝKORA, Michal: O Viktorii Tokarevové. Doslov. In: TOKAREVOVÁ, Viktoria: Římské prázdniny. Brno: Host, 2005, s. 184-188.

ŠÚTOVEC, Milan: O epikom diele. Levice: L.C.A., 1999.

prof. PhDr. Viera Žemberová, CSc.

Inštitút slovakistických, mediálnych a knižničných štúdií

Filozofická fakulta, Prešovská univerzita v Prešove

UI. 17. novembra č. 1, 08001 Prešov, Slovenská republika

viera.zemberova@ff.unipo.sk 